\title{
Review: a short course of antibiotic treatment is as effective as a standard course in children with urinary tract infection
}

\author{
Michael M, Hodson EM, Craig JC, et al. Short compared with standard duration of antibiotic treatment for urinary tract \\ infection: a systematic review of randomised controlled trials. Arch Dis Child 2002;87:118-23.
}

QUESTION: In children with urinary tract infection (UTI), what is the effectiveness of
short course $(2-4$ d) compared with standard duration (7-14 d) of antibiotic treatment?

\section{Data sources}

Studies in all languages were identified by searching Medline (1966 to February 2001), EMBASE/Excerpta Medica (1988 to February 2001), the Cochrane Library (Issue 1, 2001), bibliographies of relevant studies and textbooks, and conference abstracts.

\section{Study selection}

Studies were selected if they were randomised controlled trials (RCTs) or quasi RCTs, involved children aged 3 months to 18 years with culture proven symptomatic UTI, and compared a short course (2-4 d) with a standard duration (7-14 d) of antibiotic treatment. Only studies that used the same antibiotic in both the short and standard duration arms were included.

\section{Data extraction}

Data were extracted on participant characteristics and numbers, antibiotics used, study duration and quality, and outcomes.

\section{Main results}

10 RCTs (652 children) were included. The meta-

Source of funding: no external funding.

For correspondence: Dr E Hodson, The Children's Hospital at Westmead, Westmead, New South Wales, Australia. Elisah@chw.edu.au analysis (random effects model) showed that short duration of antibiotic treatment did not differ from standard duration for frequency of bacteriuria (colony counts $\geq 10^{5}$ organisms/ $\mathrm{ml}$ of urine) at $0-7$ days after completing treatment, recurrent UTI at 10 days to 15 months after completing treatment, or recurrent UTI caused by resistant organisms $\geq 10$ days after completing treatment (table).

Short (2-4 d) v standard (7-14d) duration of antibiotic treatment in children with urinary tract infection $(U T I)^{*}$

\begin{tabular}{lllll}
\hline Outcomes & $\begin{array}{l}\text { Short } \\
\text { course }\end{array}$ & $\begin{array}{l}\text { Standard } \\
\text { course }\end{array}$ & $\begin{array}{l}\text { Weighted RRI } \\
(95 \% \mathrm{Cl})\end{array}$ & NNH \\
$\begin{array}{l}\text { Frequency of } \\
\text { bacteriuria at } 0-7 \\
\text { days (8 studies) }\end{array}$ & $15 \%$ & $14 \%$ & $6 \%(-36$ to 76$)$ & Not significant \\
\hline $\begin{array}{l}\text { Recurrent UTI at } 10 \\
\text { days to } 15 \text { months } \\
\text { (12 studies) }\end{array}$ & $23 \%$ & $24 \%$ & $1 \%(-23$ to 33) & Not significant \\
\hline $\begin{array}{l}\text { Recurrent UTI caused } \\
\text { by resistant } \\
\text { organisms at } \geq 10 \\
\text { days (3 studies) }\end{array}$ & $11 \%$ & $33 \%$ & $61 \%(-29$ to 88$)$ & Not significant \\
\hline
\end{tabular}

*Abbreviations defined in glossary; RRR, RRI, and $\mathrm{Cl}$ calculated from data in article using a random effects model.

\section{Conclusion}

In children with urinary tract infection, a short course (2-4 d) of antibiotic treatment is as effective as a standard course (7-14 d).

\section{COMMENTARY}

The standard treatment for UTI in children is $\geq 7$ days of an appropriate antibiotic. In women (but not in men), 3 day courses are advocated for cystitis, with longer courses reserved for ascending infection. ${ }^{1}$ The reasons suggested for longer courses in children include (1) underlying urinary tract abnormality commonly presents with infection, (2) irreversible renal damage may occur in susceptible children, and (3) diagnosis is difficult in younger children.

5 systematic reviews have compared standard with short courses of antibiotics for UTI in children. They show a range of conclusions, perhaps reflecting their inclusion criteria rather than other differences.

The review of Michael $e t$ al most favours a shorter course treatment. Michael et al excluded comparisons with single day or single dose regimens. Subanalysis in 2 reviews $^{2-3}$ suggested that very short courses might be therapeutically inferior. This review also excluded RCTs using different antibiotics in treatment and control arms. However, the review itself found no influence of specific antibiotics on outcomes

The authors add several cautionary notes to their conclusion of no difference between short and standard courses. Firstly, there are wide confidence intervals. Secondly, all studies excluded children with pyelonephritis and known urinary tract pathology. Thirdly, 2 studies (1 of which was a large contributor to the meta-analysis) included children with asymptomatic bacteriuria, who may be harmed by treatment. Fourthly, all studies included children with recurrent UTI, who have higher rates of treatment failure. The authors estimate the risk of treatment failure in unselected populations (eg, in primary care populations) as between $-1.1 \%$ and $2.3 \%$, and in selected populations (ie, typical of participants) as between $-5 \%$ and $11 \%$. Therefore, what should clinicians do?

Choosing treatment length is probably secondary to identifying the very few high risk patients presenting with their first UTI. Thus, despite the scientific quality of this review, its effect may be restricted to the management of the older child (in whom clinical markers are more reliable), and to children known to be at minimal risk of complications. James Larcombe, MBChB, Dip Adv GP, FRCGP Centre for Integrated Health Care Research Durham, UK

1 PRODIGY Guidance-Urinary tract-children. www.prodigy. nhs.uk/guidance.asp?gt=uti $\% 20-0 \% 20$ children

2 Tran D, Muchant DG, Aronoff SC. Short-course versus conventional length antimicrobial therapy for uncomplicated lower urinary tract infections in children: a meta-analysis of 1279 patients. J Pediatr 2001:139.93-9.

3 Keren R, Chan E. A meta-analysis of randomized controlled Keren R, Chan E. A meta-analysis of randomized controlled
trials comparing short- and long-course antibiotic therapy trials comparing short- and long-course antibiotic therapy
for urinary tract infections in children. Pediatrics 2002; 109: E70. 